\title{
Resistance spectra of six elite breeding lines of upland rice to Pyricularia grisea ${ }^{(1)}$
}

\author{
Anne Sitarama Prabhu(2), Emílio da Maia de Castro(2), Leila Garcês de Araújo(2) \\ and Rodrigo Fascin Berni ${ }^{(3)}$
}

\begin{abstract}
The objective of this work was to evaluate the resistance spectra of six elite breeding lines of rice, developed for improved yield and grain quality, in inoculation tests in the greenhouse and in the field. Forty-six isolates of Pyricularia grisea collected from the cultivar Primavera, 31 from the cultivar Maravilha and 19 from six elite breeding lines, totaling 96 were utilized for inoculations. Out of 11 international and 15 Brazilian pathotypes, IC-1, IB-9, and BD-16, respectively, were identified as most frequent isolates collected from the cultivar Primavera. The isolates retrieved from Maravilha belong to four international and 11 Brazilian pathotypes, the predominant ones being IB-9 and IB-49 and BB-1 and BB-21, respectively. Lines $\mathrm{CNA}_{\mathrm{s}} 8711$ and $\mathrm{CNA}_{\mathrm{s}} 8983$ showed resistant reaction to all test isolates from Maravilha, while $\mathrm{CNA}_{s} 8983$ was susceptible to three isolates of Primavera pertaining to the pathotype IC-1. A majority of isolates exhibiting compatible reaction to Primavera were incompatible to Maravilha and vice-versa. Field assessment of rice blast utilizing the area under disease progress curve as a criterion for measuring disease severity showed significant differences among the six breeding lines. The isolates of $P$. grise $a$ exhibiting differential reaction on breeding lines can be utilized in pyramiding resistance genes in new upland rice cultivars.
\end{abstract}

Index terms: Oryza sativa, pathotypes, physiologic races, rice blast, inoculation methods.

Espectro de resistência de seis linhagens elites de arroz de terras altas a Pyricularia grisea

Resumo - O objetivo deste trabalho foi avaliar o espectro de resistência de seis linhagens elites de arroz de terras altas, desenvolvidas para maior produtividade e qualidade superior de grãos, através de testes de inoculação em casa de vegetação e no campo. Nos testes de inoculação, foram utilizados 96 isolados de Pyricularia grisea, sendo 46 provenientes da cultivar Primavera, 31 da cultivar Maravilha e 19 de seis linhagens elites. Os patótipos internacionais IC-1 e IB-9, e os patótipos brasileiros BD-16 foram identificados como mais freqüentes entre os isolados coletados da cultivar Primavera. Os isolados da cultivar Maravilha pertenceram a quatro patótipos internacionais e a 11 patótipos brasileiros com predominância de IB-9, IB-49, BB-1 e BB-21, respectivamente. Enquanto as linhagens CNA 8711 e $\mathrm{CNA}_{\mathrm{s}} 8983$ apresentaram reações de resistência para todos os isolados oriundos da cultivar Maravilha, $\mathrm{CNA}_{\mathrm{s}} 8983$ mostrou reação suscetível para três isolados de Primavera, pertencentes ao patótipo IC-1. A maioria dos isolados que apresentaram reações compatíveis com a cultivar Primavera foram incompatíveis com a cultivar Maravilha e vice-versa. As avaliações no campo mostraram diferenças significativas entre as linhagens com relação à área sob curva de progresso da brusone nas folhas. Os isolados de $P$. grisea que apresentaram reações diferenciais nas linhagens podem ser utilizados para a piramidação de genes em novas cultivares de arroz de terras altas.

Termos para indexação: Oryza sativa, patótipos, raças fisiológicas, brusone, métodos de inoculação.

(1) Accepted for publication on September 30, 2002.

(2) Embrapa-Centro Nacional de Pesquisa de Arroz e Feijão, Caixa Postal 179, CEP 75375-000 Santo Antônio de Goiás, GO, Brazil E-mail: prabhu@cnpaf.embrapa.br, emilio@cnpaf.embrapa.br, leilag@cnpaf.embrapa.br

(3) Embrapa-Centro de Pesquisa Agroflorestal da Amazônia Ocidental, Rod. AM-010, Km 29, CEP 69011-970 Manaus, AM, Brazil. E-mail: rodrigo@cpaa.embrapa.br

\section{Introduction}

A technological revolution in the upland rice cultivar improvement for superior grain quality and yield was witnessed in the last decade, in Brazil. The release of the cultivars without adequate degree of blast resistance has enhanced the destructive 
potential of Pyricularia grisea (Cooke) Sacc. [=Magnaporthe grisea (Herbert) Barr]. Rice breeding for blast resistance has been one of the major goals of research program of Embrapa-Centro Nacional de Pesquisa de Arroz e Feijão, Santo Antônio de Goiás, GO, Brazil. Several of the recently released upland rice cultivars such as Caiapó, Canastra, Confiança, Maravilha and Primavera exhibit different degrees of blast resistance (Prabhu \& Filippi, 1999). It is widely recognized that when a cultivar is extensively grown, the pathotypes matching to resistance genes will increase in their frequency resulting in greater susceptibility. The high virulence frequency of P. grisea population on cultivars IAC 47 and IAC 165 explained the high degree of susceptibility of these cultivars as compared to other upland rice cultivars under field conditions. The low frequency of pathotypes virulent on cultivar Araguaia indicates its moderate resistance (Filippi \& Prabhu, 2001).

The susceptibility of the widely grown cultivars Maravilha and Primavera has increased since their release in 1996, and the grain yield losses have been considered significant. The available information on pathotypes of $P$. grisea affecting these cultivars and their frequency is limited. Evaluation of improved breeding lines for resistance, before their release, to the most prevalent pathotypes of P. grisea in extensively grown commercial rice cultivars is important to predict in advance their field performance. These results would allow more judicious choices in releasing these lines as new rice cultivars. Furthermore, information on diversity in specific virulence in the pathogen population is valuable to choose the parents to be utilized in crosses directed for breeding blast resistant cultivars.

The objective of this work was to evaluate the resistance spectra of six elite breeding lines of rice, developed for improved yield and grain quality, in inoculation tests in the greenhouse and in the field.

\section{Material and Methods}

Collection of isolates of $P$. grisea were made from sporulating lesions on leaves of the cultivars Primavera, Maravilha, and six other improved advanced breeding lines $\left(\mathrm{CNA}_{\mathrm{s}} 8711, \mathrm{CNA}_{\mathrm{s}} 8934, \mathrm{CNA}_{\mathrm{s}} 8812, \mathrm{CNA}_{\mathrm{s}} 8170\right.$, $\mathrm{CNA}_{\mathrm{s}} 8540$ and $\mathrm{CNA}_{\mathrm{s}} 8983$ ) in experimental plots located at the Embrapa-Centro Nacional de Pesquisa de Arroz e
Feijão, Santo Antônio de Goiás, GO, Brazil, from 1997 to 2001. Single conidial isolates were conserved on sterilized filter paper discs at $4 \pm 1^{\circ} \mathrm{C}$ in the refrigerator. Forty six isolates of $P$. grise a collected from the cultivar Primavera, 31 from the cultivar Maravilha and 19 from six elite breeding lines, totaling 96 were utilized in inoculation tests. The virulence frequency of these isolates was tested under controlled greenhouse conditions, utilizing 32 genotypes including six elite upland rice breeding lines, four commercial rice cultivars (Aimoré, Bonança, Canastra and Carisma), a somaclone of cultivar Araguaia (SC 09) with a known gene as a check for vertical resistance, eight standard international differentials (Dular, Kanto 51, NP125, Raminad Str 3, Usen, Zenith, Caloro and Sha-tia-tsão), eight Brazilian local differentials (Carajás, Confiança, Maravilha, Primavera, Progresso, Caiapó, IAC-47 and IAC-201) and five near isogenic lines of CO 39 (C 101 LAC, C101A 51, C104 PKT, C101 PKT and C101-TTP-4L-23). The test material was planted in plastic trays (30x $15 \times 10 \mathrm{~cm})$ containing $3 \mathrm{~kg}$ of soil fertilized with NPK ( $5 \mathrm{~g}$ of $5-30-15+\mathrm{Zn}$ and $3 \mathrm{~g}$ of ammonium sulfate per $3 \mathrm{~kg}$ of soil). An additional $2 \mathrm{~g}$ of ammonium sulfate per tray was applied 20 days after planting. Ten to twelve seeds of each entry were sown in $4 \mathrm{~cm}$ long rows totaling 16 rows per tray, eight on each half of the tray.

Mycelial growth, sporulation on culture medium and inoculation procedure were carried out as described in earlier investigations (Prabhu et al., 1992; Filippi \& Prabhu, 2001). Leaf blast reaction was assessed seven to nine days after inoculation taking into consideration only two types of reaction of the host, compatible (susceptible) and incompatible (resistant). The lesion types $0,1,2$ and 3 were considered as resistant, and 4 to 9 as susceptible, in a 0-9 SAS scale (International Rice Research Institute, 1988). Inoculation tests were repeated twice, and in case of ambiguous or intermediate reaction, the test was repeated again and those which gave consistent and uniform reaction were utilized. A tray containing international and Brazilian differential hosts as a non-inoculated control was maintained to ensure that no contamination occurred during the inoculation procedure.

International pathotype identification was based on the eight international differentials (Atkins et al., 1967). The Brazilian pathotypes were differentiated on the basis of reaction on eight local commercial upland rice cultivars (Prabhu et al., 2002). The international and Brazilian pathotypes were prefixed by the letter "I" and "B", respectively. The numbers following the group letters indicate the pathotype number. The numbering of international pathotypes and the same key with reaction patterns of international differentials (Ling \& Ou, 1969) were used for designating Brazilian pathotypes. Even 
though 32 genotypes were included in the tests, the present investigation was restricted to the analysis of leaf blast reaction of the elite breeding lines and pathotype identification based on the reaction pattern on international and Brazilian differentials.

During 2000/2001 rice growing seasons, the level of blast resistance, of the six advanced upland rice breeding lines $\left(\mathrm{CNA}_{\mathrm{s}} 8711, \mathrm{CNA}_{\mathrm{s}} 8934, \mathrm{CNA}_{\mathrm{s}} 8812, \mathrm{CNA}_{\mathrm{s}} 8170\right.$, $\mathrm{CNA}_{\mathrm{s}} 8540$ and $\mathrm{CNA}_{\mathrm{s}} 8983$ ) and two commercial rice cultivars (Maravilha and Primavera) were assessed, under natural conditions of infection, in a field experiment, utilizing a randomized complete block design with four replications.

Each plot consisted of six rows, $0.5 \mathrm{~m}$ long and $0.35 \mathrm{~m}$ apart. Three rows of a mixture of highly susceptible cultivars (IAC 47, Rio Paranaíba and Guarani) were planted on both sides of the block, perpendicular to the lines, as spreaders. Plots were fertilized at planting with $400 \mathrm{~kg} / \mathrm{ha}$ (4-30-15) of NPK in addition to $125 \mathrm{~kg} / \mathrm{ha}$ of ammonium sulfate, $20 \mathrm{~kg} / \mathrm{ha}$ of zinc sulfate and $20 \mathrm{~kg} / \mathrm{ha}$ of micronutrients FTE-BR 12 (Ferro Enamel do Brazil Ind. Com. Ltd., São Paulo, Brazil). Seeds were drill planted in plots at the rate of 80 seeds/m on February 9, 2001.
Leaf blast assessment was made on four fully opened leaves, of main tiller of each plant, in two central rows of each plot. The percentage of leaf area affected was measured utilizing a 10 grade scale according to Notteghem (1981). Disease observations were made at intervals of three days starting from the first appearance of disease symptom on the susceptible check cultivar on March 6 until March 15, 2001.

The area under disease progress curves (AUDPC) was computed for each cultivar according to Shaner \& Finney (1977). Log transformation of data was performed to reduce the heterogeneity of variance because of the association between mean and standard deviation. Analysis of variance (ANOVA) was made with the transformed values and the means were separated by Tukey's test at $5 \%$ of probability.

\section{Results and Discussion}

The elite breeding lines exhibited differences in reaction pattern to the isolates of $P$. grisea retrieved from these lines (Table 1). The line $\mathrm{CNA}_{\mathrm{S}} 8983$ showed resistant reaction to all 19 isolates tested.

Table 1. Reaction of six elite breeding lines and commercial rice cultivars Primavera and Maravilha to field isolates of Pyricularia grisea retrieved from five of these lines (Santo Antônio de Goiás, 2000/2001).

\begin{tabular}{|c|c|c|c|c|c|c|c|c|c|c|}
\hline \multirow[t]{2}{*}{ Isolate $^{(1)}$} & \multirow{2}{*}{$\begin{array}{l}\text { International } \\
\text { pathotype }^{(2)}\end{array}$} & \multirow{2}{*}{$\begin{array}{c}\text { Brazilian } \\
\text { pathotype }^{(3)}\end{array}$} & \multicolumn{6}{|c|}{ Elite breeding lines ${ }^{(4)}$} & \multicolumn{2}{|c|}{ Commercial cultivars } \\
\hline & & & 1 & 2 & 3 & 4 & 5 & 6 & Primavera & Maravilha \\
\hline Py 3008-1 & IB-41 & BA-1 & $\mathrm{R}$ & $\mathrm{R}$ & $\mathrm{R}$ & $\mathrm{R}$ & $\mathrm{R}$ & $\mathrm{R}$ & $\mathrm{S}$ & $\mathrm{S}$ \\
\hline Рy 3012-1 & IB-1 & BA-1 & $\mathrm{S}$ & $\mathrm{S}$ & $\mathrm{R}$ & $\mathrm{R}$ & $\mathrm{R}$ & $\mathrm{R}$ & $\mathrm{S}$ & $\mathrm{S}$ \\
\hline Py 3013-1 & IB-1 & BA-9 & $\mathrm{R}$ & $\mathrm{R}$ & $\mathrm{R}$ & $\mathrm{R}$ & $\mathrm{R}$ & $\mathrm{R}$ & $\mathrm{S}$ & S \\
\hline Рy 3025-2 & IB-9 & BB-1 & $\mathrm{R}$ & $\mathrm{R}$ & $\mathrm{S}$ & $\mathrm{S}$ & $\mathrm{S}$ & $\mathrm{R}$ & $\mathrm{S}$ & $\mathrm{S}$ \\
\hline Py $3026-2$ & IB-9 & BD-1 & $\mathrm{R}$ & $\mathrm{R}$ & $\mathrm{R}$ & $\mathrm{R}$ & $\mathrm{R}$ & $\mathrm{R}$ & $\mathrm{S}$ & $\mathrm{R}$ \\
\hline Рy 3027-2 & IB-33 & BD-1 & $\mathrm{R}$ & $\mathrm{R}$ & $\mathrm{R}$ & $\mathrm{R}$ & $\mathrm{R}$ & $\mathrm{R}$ & $\mathrm{S}$ & $\mathrm{R}$ \\
\hline Рy 3028-2 & IB-33 & BA-41 & $\mathrm{R}$ & $\mathrm{R}$ & $\mathrm{R}$ & $\mathrm{R}$ & $\mathrm{R}$ & $\mathrm{R}$ & $\mathrm{S}$ & $\mathrm{R}$ \\
\hline Py $3014-3$ & IB-41 & BA-9 & $\mathrm{R}$ & $\mathrm{R}$ & $\mathrm{R}$ & $\mathrm{R}$ & $\mathrm{R}$ & $\mathrm{R}$ & $\mathrm{R}$ & $\mathrm{R}$ \\
\hline Py $3015-3$ & IB-15 & BB-22 & $\mathrm{R}$ & $\mathrm{R}$ & $\mathrm{S}$ & $\mathrm{S}$ & $\mathrm{S}$ & $\mathrm{R}$ & $\mathrm{R}$ & $\mathrm{S}$ \\
\hline Py 3018-3 & IB-9 & BB-1 & $\mathrm{R}$ & $\mathrm{R}$ & $\mathrm{R}$ & $\mathrm{R}$ & $\mathrm{R}$ & $\mathrm{R}$ & $\mathrm{S}$ & $\mathrm{S}$ \\
\hline Py 3019-3 & IB-9 & BD-9 & $\mathrm{R}$ & $\mathrm{R}$ & $\mathrm{R}$ & $\mathrm{R}$ & $\mathrm{R}$ & $\mathrm{R}$ & $\mathrm{S}$ & $\mathrm{R}$ \\
\hline Py $3002-5$ & IB-9 & BB-21 & $\mathrm{R}$ & $\mathrm{R}$ & $\mathrm{S}$ & $\mathrm{S}$ & $\mathrm{S}$ & $\mathrm{R}$ & $\mathrm{R}$ & $S$ \\
\hline Py $3003-5$ & IB-9 & BB-21 & $\mathrm{R}$ & $\mathrm{R}$ & $\mathrm{S}$ & $\mathrm{S}$ & $\mathrm{S}$ & $\mathrm{R}$ & $\mathrm{R}$ & $\mathrm{S}$ \\
\hline Py $3005-5$ & IB-45 & BB-23 & $\mathrm{R}$ & $\mathrm{R}$ & $\mathrm{S}$ & $\mathrm{S}$ & $\mathrm{S}$ & $\mathrm{R}$ & $\mathrm{R}$ & $\mathrm{S}$ \\
\hline Py 3006-5 & IB-45 & BB-21 & $\mathrm{R}$ & $\mathrm{R}$ & $\mathrm{S}$ & $\mathrm{S}$ & $\mathrm{R}$ & $\mathrm{R}$ & $\mathrm{R}$ & $\mathrm{S}$ \\
\hline Py 3021-6 & IF-1 & BC-32 & $\mathrm{R}$ & $\mathrm{R}$ & $\mathrm{R}$ & $\mathrm{R}$ & $\mathrm{R}$ & $\mathrm{R}$ & $\mathrm{R}$ & $\mathrm{S}$ \\
\hline Py $3022-6$ & IC-25 & BB-21 & $\mathrm{R}$ & $\mathrm{R}$ & $\mathrm{R}$ & $\mathrm{R}$ & $\mathrm{R}$ & $\mathrm{R}$ & $\mathrm{S}$ & $\mathrm{R}$ \\
\hline Рy 3023-6 & IC-26 & BD-16 & $\mathrm{R}$ & $\mathrm{R}$ & $\mathrm{R}$ & $\mathrm{R}$ & $\mathrm{R}$ & $\mathrm{R}$ & $\mathrm{S}$ & $\mathrm{R}$ \\
\hline Py 3024-6 & IB-17 & BD-16 & $\mathrm{S}$ & $\mathrm{S}$ & $\mathrm{R}$ & $\mathrm{R}$ & $\mathrm{R}$ & $\mathrm{R}$ & $\mathrm{S}$ & $\mathrm{R}$ \\
\hline Total number & - & - & 2 & 2 & 6 & 6 & 5 & 0 & 12 & 11 \\
\hline
\end{tabular}

(1) The number following the code number of the isolate indicate the breeding line from which the isolate was collected. (2)International pathotypes were identified based on the reaction pattern on eight international standard differentials. ${ }^{(3)}$ Brazilian pathotypes were identified using eight local upland rice cultivars as additional differentials. ${ }^{(4)}$ Elite breeding lines $1: \mathrm{CNA}_{\mathrm{S}} 8711 ; 2: \mathrm{CNA}_{\mathrm{S}} 8934 ; 3: \mathrm{CNA}_{\mathrm{S}} 8812 ; 4: \mathrm{CNA}_{\mathrm{S}} 8170 ; 5: \mathrm{CNA}_{\mathrm{S}} 8540$; 6: $\mathrm{CNA}_{\mathrm{S}}$ 8983; R: resistant; S: susceptible. 
On the other hand, the lines $\mathrm{CNA}_{\mathrm{S}} 8812$ and $\mathrm{CNA}_{S} 8170$ were susceptible to six and $\mathrm{CNA}_{S} 8540$, to five isolates. Some isolates of $P$. grisea were not compatible to the same line from which they were collected. These results are in conformity with those obtained in earlier studies with commercial rice cultivars (Prabhu \& Filippi, 2001). This phenomenon was explained by the production of conidia of different virulence pattern and broad resistance spectrum of the cultivars (Ou, 1980; Correa-Victoria \& Zeigler, 1993). However, the possibility of contamination of sporulating lesions, under field conditions, with spores coming from the neighboring lines or cultivars cannot be overlooked. The single spore isolates were made after incubating the leaves with leaf lesions for 24 hours in Petri plates, under humid conditions for sporulation, without sterilization.

The international pathotype IB-9 and Brazilian pathotype BB-21 were predominant among the isolates collected from five of the six breeding lines (Table 1). Four isolates from the same line such as CNA $_{S} 8983$ pertain to four and three different international and Brazilian pathotypes, respectively, indicating the existence of diversity in virulence among the isolates of $P$. grisea to the six breeding lines. The cultivars Primavera and Maravilha showed differential reaction to 13 of 19 isolates tested. Six were compatible to both cultivars while the pathotype IB-41/BA-9 was not compatible to any of the six breeding lines as well as Primavera and Maravilha. Some of the isolates compatible with $\mathrm{CNA}_{S} 8540$ were not compatible with Primavera and vice-versa indicating that these two genotypes possess at least one major gene not present in the other. In a similar manner, the lines appear to carry different genes which condition resistance against different isolates or pathotypes tested in this study. These lines were obtained by triple or multiple crosses involving diverse sources of resistance with unknown genes. Even cultivars considered to be widely susceptible such as Primavera may possess resistance genes against certain pathotypes and is useful in a breeding program directed towards resistance improvement.

Based on the reaction pattern of eight international differentials, 11 pathotypes were identified in a sample population of $46 P$. grisea isolates collected from the upland rice cultivar
Primavera (Table 2). The predominant international pathotypes were IC-1 and IB-9. The frequency of isolates compatible with the six breeding lines was very low. The lines $\mathrm{CNA}_{\mathrm{S}} 8812, \mathrm{CNA}_{\mathrm{S}} 8170$ and $\mathrm{CNA}_{\mathrm{S}} 8540$ were susceptible to six isolates of the pathotype IB-9 whereas $\mathrm{CNA}_{\mathrm{S}} 8983$ to three of the IC-1.

Fifteen Brazilian pathotypes were identified utilizing eight commercial upland rice cultivars as differentials in contrast to 11 international pathotypes (Table 2). They represented groups BA, $\mathrm{BB}, \mathrm{BC}, \mathrm{BD}, \mathrm{BE}$ and $\mathrm{BG}$. The most predominant Brazilian pathotype BB-16 was identified based on the susceptible reaction of three differentials Confiança, Maravilha and Primavera. It represented $52.2 \%$ of the 46 isolates of the cultivar Primavera. The line $\mathrm{CNA}_{\mathrm{S}} 8983$ exhibited susceptible reaction to four isolates of BD-16. This pathotype was specific to the cultivar Primavera and did not show compatible reaction to other differentials. The lines $\mathrm{CNA}_{\mathrm{S}} 8812$, $\mathrm{CNA}_{S} 8170$ and $\mathrm{CNA}_{\mathrm{S}} 8540$ were susceptible to the pathotype BA-1 which induces susceptible reaction to all Brazilian differentials except Carajas. These results showed that the resistance spectra of improved lines is high to isolates of $P$. grisea from the cultivar Primavera.

In contrast to the isolates from the cultivar Primavera, a relatively high frequency of isolates from the cultivar Maravilha, pertaining to the predominant pathotypes IB-9 and IB-41, showed compatible reaction to the lines $\mathrm{CNA}_{\mathrm{S}} 8812, \mathrm{CNA}_{\mathrm{S}} 8170$ and CNA $_{S} 8540$ (Table 3). None of the 31 isolates collected from cultivar Maravilha were compatible to the lines $\mathrm{CNA}_{\mathrm{S}} 8711$ and $\mathrm{CNA}_{\mathrm{S}}$ 8983. The predominance of the pathotypes IB- 9 and IB-41 among isolates of Maravilha was also encountered in isolates of $P$. grisea retrieved from upland rice cultivars (Filippi \& Prabhu, 1996, 2001; Prabhu \& Filippi, 2001). The pathotype IC-1 found in a high frequency was specific to the cultivar Primavera whereas the pathotype IB-9 was commonly encountered among isolates of both cultivars Primavera and Maravilha. The pathotypes representing other groups IA, ID, and IF obtained from the cultivars Primavera and Maravilha and six breeding lines were in a low frequency. The 
predominant Brazilian pathotypes BB-1, BB-21 and BB-29 were also compatible to the lines $\mathrm{CNA}_{\mathrm{S}} 8812$, $\mathrm{CNA}_{S} 8170$ and $\mathrm{CNA}_{\mathrm{S}} 8540$.

Several pathotypes or races were identified in this study, but the pathotype may not necessarily be the most appropriate phenotypic unit for resistance breeding program, because 71 distinct virulence patterns were observed on the 21 cultivars tested (Zeigler et al., 1995). The number of pathotypes increase as more isolates are tested (Ou, 1980). International races representing all race groups were recovered in Brazil from both upland and irrigated rice cultivars in different rice growing States
(Malavolta \& Souza, 1992; Filippi \& Prabhu, 1996; Prabhu \& Filippi, 2001). Information on isolate $\mathrm{x}$ cultivar interaction would be valuable for incorporating resistance genes against a specific isolate pertaining to a given pathotype. However, the pathotype determination based on local Brazilian differentials will be more useful in the studies on population dynamics and the resistance gene frequencies that are useful in breeding. In studies on the diversity of agriculturally important isolates of P. grisea, the use of widely grown local cultivars as differential set is preferable (Bonman et al., 1986). To determine the population structure, the disease

Table 2. Pathotypes and frequency of compatible isolates of Pyricularia grisea retrieved from the cultivar Primavera to six breeding lines and two commercial rice cultivars (Santo Antônio de Goiás, 2000/2001).

\begin{tabular}{|c|c|c|c|c|c|c|c|c|c|}
\hline \multirow[t]{2}{*}{ Pathotype } & \multirow{2}{*}{$\begin{array}{l}\text { Number of } \\
\text { isolates }^{(1)}\end{array}$} & \multicolumn{2}{|c|}{ Commercial cultivars } & \multicolumn{6}{|c|}{ Breeding lines } \\
\hline & & Primavera & Maravilha & $\begin{array}{l}\mathrm{CNA}_{\mathrm{S}} \\
8711 \\
\end{array}$ & $\begin{array}{c}\mathrm{CNA}_{\mathrm{S}} \\
8934 \\
\end{array}$ & $\begin{array}{l}\mathrm{CNA}_{\mathrm{S}} \\
8812 \\
\end{array}$ & $\begin{array}{c}\mathrm{CNA}_{\mathrm{S}} \\
8170\end{array}$ & $\begin{array}{c}\mathrm{CNA}_{\mathrm{S}} \\
8540 \\
\end{array}$ & $\begin{array}{c}\mathrm{CNA}_{\mathrm{S}} \\
8983 \\
\end{array}$ \\
\hline \multicolumn{10}{|c|}{ International $^{(2)}$} \\
\hline IC-1 & 13 & 12 & 0 & 0 & 0 & 0 & 0 & 0 & 3 \\
\hline IB-9 & 11 & 11 & 5 & 0 & 0 & 4 & 4 & 6 & 0 \\
\hline IC-25 & 7 & 7 & 1 & 0 & 0 & 0 & 0 & 0 & 0 \\
\hline IC-9 & 3 & 3 & 0 & 0 & 0 & 0 & 0 & 0 & 0 \\
\hline IC-17 & 3 & 2 & 0 & 0 & 0 & 0 & 0 & 0 & 0 \\
\hline IA-9 & 3 & 3 & 0 & 0 & 0 & 0 & 0 & 0 & 0 \\
\hline IA-65 & 2 & 2 & 0 & 0 & 0 & 0 & 0 & 0 & 0 \\
\hline IA-73 & 1 & 1 & 0 & 0 & 0 & 0 & 0 & 0 & 0 \\
\hline IB-33 & 1 & 1 & 0 & 0 & 0 & 0 & 0 & 0 & 0 \\
\hline ID-9 & 1 & 1 & 0 & 0 & 0 & 0 & 0 & 0 & 0 \\
\hline IF-1 & 1 & 1 & 0 & 0 & 0 & 0 & 0 & 0 & 0 \\
\hline \multicolumn{10}{|c|}{ Brazilian $^{(3)}$} \\
\hline BD-16 & 24 & 24 & 0 & 0 & 0 & 0 & 0 & 0 & 4 \\
\hline BB-41 & 5 & 4 & 0 & 0 & 0 & 0 & 0 & 1 & 0 \\
\hline BD-9 & 4 & 4 & 0 & 0 & 0 & 0 & 0 & 0 & 0 \\
\hline BD-5 & 2 & 2 & 2 & 0 & 0 & 2 & 2 & 2 & 0 \\
\hline BA-1 & 1 & 1 & 1 & 0 & 0 & 1 & 1 & 1 & 0 \\
\hline BB-1 & 1 & 1 & 1 & 0 & 0 & 1 & 0 & 1 & 0 \\
\hline BB-6 & 1 & 1 & 1 & 0 & 0 & 0 & 1 & 1 & 0 \\
\hline BB-11 & 1 & 1 & 0 & 0 & 0 & 0 & 0 & 0 & 0 \\
\hline BB-46 & 1 & 1 & 0 & 0 & 0 & 0 & 0 & 0 & 0 \\
\hline BC-16 & 1 & 1 & 1 & 0 & 0 & 0 & 0 & 0 & 0 \\
\hline BD-1 & 1 & 1 & 0 & 0 & 0 & 0 & 0 & 0 & 0 \\
\hline BD-11 & 1 & 1 & 0 & 0 & 0 & 0 & 0 & 0 & 0 \\
\hline BD-13 & 1 & 1 & 0 & 0 & 0 & 0 & 0 & 0 & 0 \\
\hline BE-8 & 1 & 0 & 0 & 0 & 0 & 0 & 0 & 0 & 0 \\
\hline BG-2 & 1 & 0 & 0 & 0 & 0 & 0 & 0 & 0 & 0 \\
\hline
\end{tabular}

${ }^{(1)}$ Total number of field isolates of $P$. grisea utilized in inoculation tests $=46 .{ }^{(2)}$ International pathotypes were identified based on reaction on eight standard international differentials. ${ }^{(3)}$ Brazilian pathotypes were identified using eight local upland rice cultivars as additional differentials. 
samples should be collected at random for testing, to avoid biased results. In the present study, $P$. grisea isolates were collected at random from leaf lesions in the experimental plots from 1997 until 2001.

All improved lines showed different degrees of leaf blast severity in the tests conducted under natural field conditions of infection. Considering AUDPC as a measure of disease severity, the lines CNA 8812 , $\mathrm{CNA}_{S} 8711, \mathrm{CNA}_{S} 8934$ and CNA 8983 were superior in resistance when compared to the cultivar Primavera but the AUDPC values did not differ significantly from the cultivar Maravilha (Figure 1). The cultivar Primavera had highest value of AUDPC followed by $\mathrm{CNA}_{\mathrm{S}} 8540, \mathrm{CNA}_{\mathrm{S}} 8170$ and the cultivar Maravilha. These results showed that the selection of lines based on resistant reaction to certain pathotypes or isolates to leaf blast will not ensure the degree of resistance required under field conditions but the frequency of compatible isolates to a given genotype will indicate the degree of resistance.
The resistance level of the elite breeding lines $\mathrm{CNA}_{\mathrm{S}} 8711$ and $\mathrm{CNA}_{\mathrm{S}} 8540$, which will be released as new upland rice cultivars, and the structure of pathogen population on the commercial rice cultivars Primavera and Maravilha allow breeders to anticipate changes in pathogen virulence and to rationalize the selection of resistance genes of value in these lines, for future crosses in the breeding program.

In a breeding site where multiple pathotypes are present, the degree of field susceptibility of a line may not be a good indicator of the potential utility of the genes it carries. The line $\mathrm{CNA}_{S} 8540$ showed high susceptibility in the field but showed resistance to specific isolates in inoculation tests. The analysis of resistance spectra of improved lines have suggested that both Brazilian and international pathotypes, compatible with them, are distinct. There was a tendency to recover the same pathotypes from a particular line or cultivar suggesting pathotype specificity to the host genotype. In the past, the rapid breakdown of resistance of the newly released

Table 3. Pathotypes and compatibility frequency of Pyricularia grisea isolates retrieved from the cultivar Maravilha to six breeding lines and two commercial rice cultivars (Santo Antônio de Goiás, 2000/2001).

\begin{tabular}{|c|c|c|c|c|c|c|c|c|c|}
\hline \multirow[t]{2}{*}{ Pathotype } & \multirow{2}{*}{$\begin{array}{c}\text { Number of } \\
\text { isolates }\end{array}$} & \multicolumn{2}{|c|}{ Commercial cultivars } & \multicolumn{6}{|c|}{ Breeding lines } \\
\hline & & Primavera & Maravilha & $\begin{array}{l}\mathrm{CNA}_{\mathrm{S}} \\
8711\end{array}$ & $\begin{array}{c}\mathrm{CNA}_{\mathrm{S}} \\
8934\end{array}$ & $\begin{array}{c}\mathrm{CNA}_{\mathrm{S}} \\
8812\end{array}$ & $\begin{array}{c}\mathrm{CNA}_{\mathrm{S}} \\
8170\end{array}$ & $\begin{array}{c}\mathrm{CNA}_{\mathrm{S}} \\
8540\end{array}$ & $\begin{array}{c}\mathrm{CNA}_{\mathrm{S}} \\
8983\end{array}$ \\
\hline \multicolumn{10}{|c|}{ International $^{(1)}$} \\
\hline IB-9 & 16 & 8 & 15 & 0 & 0 & 15 & 13 & 16 & 0 \\
\hline IB-41 & 12 & 3 & 11 & 0 & 1 & 12 & 11 & 11 & 0 \\
\hline IA-9 & 2 & 0 & 1 & 0 & 0 & 2 & 2 & 2 & 0 \\
\hline IA-41 & 1 & 0 & 1 & 0 & 0 & 1 & 1 & 1 & 0 \\
\hline \multicolumn{10}{|c|}{ Brazilian $^{(2)}$} \\
\hline BB-1 & 8 & 8 & 8 & 0 & 0 & 8 & 7 & 8 & 0 \\
\hline BB-21 & 5 & 0 & 5 & 0 & 0 & 5 & 5 & 5 & 0 \\
\hline BB-29 & 4 & 0 & 4 & 0 & 0 & 4 & 3 & 4 & 0 \\
\hline BB-17 & 2 & 0 & 2 & 0 & 0 & 2 & 2 & 2 & 0 \\
\hline BB-22 & 2 & 0 & 2 & 0 & 0 & 2 & 1 & 2 & 0 \\
\hline BB-30 & 2 & 0 & 2 & 0 & 0 & 2 & 2 & 2 & 0 \\
\hline BB-61 & 2 & 0 & 0 & 0 & 0 & 1 & 1 & 2 & 0 \\
\hline BB-5 & 1 & 1 & 1 & 0 & 0 & 1 & 1 & 1 & 0 \\
\hline BB-6 & 1 & 1 & 1 & 0 & 0 & 1 & 1 & 1 & 0 \\
\hline BB-13 & 1 & 1 & 1 & 0 & 0 & 1 & 1 & 1 & 0 \\
\hline BB-25 & 1 & 0 & 1 & 0 & 0 & 1 & 1 & 1 & 0 \\
\hline BB-31 & 1 & 0 & 1 & 0 & 0 & 1 & 1 & 1 & 0 \\
\hline IG-2 & 1 & 0 & 0 & 0 & 0 & 1 & 1 & 1 & 0 \\
\hline
\end{tabular}

${ }^{(1)}$ International pathotypes were identified based on reaction on eight standard international differentials. ${ }^{(2)}$ Brazilian pathotypes were identified using eight local upland rice cultivars as additional differentials. 
cultivars has been over emphasized to pathotype diversity, instability in isolates, disease escape in breeding nurseries (Ou, 1980; Zeigler et al., 1995) rather than increase in frequency of preexisting pathotypes with the release of a new cultivar. The occurrence of pathotypes of $P$. grisea isolates from cultivars Primavera and Maravilha, compatible to improved breeding lines even though in low frequency, showed the preexistence of the virulence for genes in the elite breeding lines, which have never been utilized.

Genetic divergence in relation to leaf blast resistance among these lines was evident. Genes from these cultivars and lines could be combined to obtain resistance to the entire spectra of predominant pathotypes. Transferring blast resistance genes by conventional back cross breeding and by molecular assisted selection may be a promising line of research, which is underway.

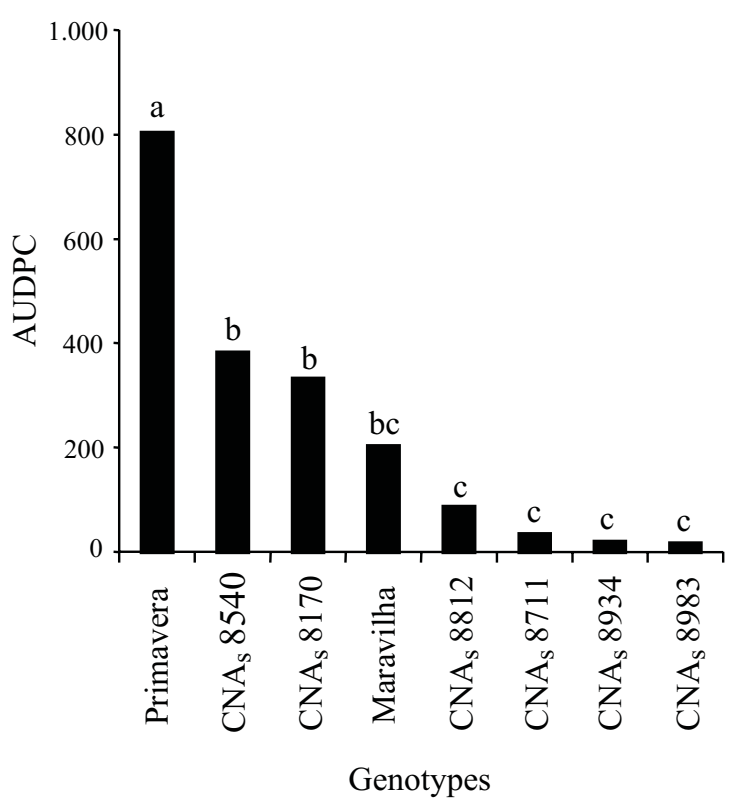

Figure 1. Area under disease progress curve (AUDPC) of leaf blast in six elite breeding lines and commercial rice cultivars Primavera and Maravilha under natural conditions of infection in experimental plots. Means followed by the same letter do not differ significantly according to Tukey's test at $5 \%$ of probability.

\section{Conclusions}

1. The improved breeding lines show different degrees of susceptibility under natural field conditions of infection.

2. Cross inoculations with isolates of $P$. grisea on breeding lines from which they are collected show differential interaction among isolates pertaining to a given pathotype and the elite breeding lines.

3 . Both virulent and avirulent pathotypes of P. grisea to the elite breeding lines are preexistent among the isolates collected from the commercial upland rice cultivars Primavera and Maravilha.

4. The pathotypes IC-1 and IB-9 among isolates of $P$. grisea collected from the cultivar Primavera and IB-9 and IB-41 from the cultivar Maravilha are predominant.

\section{References}

ATKINS, J. G.; ROBERT, A. L.; ADAAIR, C. R.; GOTO, K.; KOZAKA, T.; YANAGIDA, R.; YAMADA, M.; MATSUMOTO, S. An international set of rice varieties for differentiating races of Pyricularia oryzae. Phytopathology, St. Paul, v. 57, p. 297-301, 1967.

BONMAN, J. M.; DIOS, V. T. I. de; KHIN, M. M. Physiologic specialization of Pyricularia oryzae in the Philippines. Plant Disease, St. Paul, v. 70, p. 767-769, 1986.

CORREA-VICTORIA, F. J.; ZEIGLER, R. S. Pathogenic variability in Pyricularia grisea at a rice blast "hot-spot" breeding site in Eastern Colombia. Plant Disease, St. Paul, v. 77, p. 1029-1035, 1993.

FILIPPI, M. C.; PRABHU, A. S. Inheritance of blast resistance in rice to two Pyricularia grisea races, IB-1 and IB-9. Brazilian Journal of Genetics, Ribeirão Preto, v. 19, p. 599-604, 1996.

FILIPPI, M. C.; PRABHU, A. S. Phenotypic virulence analysis of Pyricularia grisea isolates from Brazilian upland rice cultivars. Pesquisa Agropecuária Brasileira, Brasília, v. 36, n. 1, p. 27-35, jan. 2001.

INTERNATIONAL RICE RESEARCH INSTITUTE (Los Baños, Philippines). Standard evaluation system for rice. Manila, 1988. $54 \mathrm{p}$.

LING, K. C.; OU, S. H. Standardization of the international race numbers of Pyricularia oryzae. Phytopathology, St. Paul, v. 59, p. 339-342, 1969. 
MALAVOLTA, V. M. A.; SOUZA, T. M. W. Variabilidade de Pyricularia oryzae no Estado de São Paulo. Summa Phytopathologica, Piracicaba, v. 18, p. 287-290, 1992.

NOTTEGHEM, J. L. Cooperative experiment on horizontal resistance to rice blast. In: INTERNATIONAL RICE RESEARCH INSTITUTE (Los Baños, Philippines). Blast and upland rice: report and recommendations from the meeting for international collaboration in upland rice improvement. Los Baños, 1981. p. 43-51.

OU, S. H. Pathogen variability and host resistance in rice blast disease. Annual Review of Phytopathology, Palo Alto, v. 18, p. 167-187, 1980.

PRABHU, A. S.; FILIPPI, M. C. Graus de resistência a brusone e produtividade de cultivares melhoradas de arroz de terras altas. Pesquisa Agropecuária Brasileira, Brasília, v. 36, n. 12, p. 1453-1459, dez. 2001.

PRABHU, A. S.; FILIPPI, M. C. Impacto de uso de cultivares resistentes no manejo de fungicidas nas cultivares de arroz. In: REUNIÃO NACIONAL DE PESQUISA DE ARROZ, 6., 1998, Goiânia. Anais... Santo Antônio de
Goiás: Embrapa-CNPAF, 1999. v. 2, p. 151-169. (Documentos, 96).

PRABHU, A. S.; FILIPPI, M. C.; ARAÚJO, L. G. Pathotype diversity of Pyricularia grisea from improved upland rice cultivars in experimental plots. Fitopatologia Brasileira, Brasília, v. 27, n. 5, p. 468-473, 2002.

PRABHU, A. S.; FILIPPI, M. C.; CASTRO, N. Pathogenic variation among isolates of Pyricularia oryzae affecting, rice, wheat, and grasses in Brazil. Tropical Pest Management, London, v. 36, p. 367-377, 1992.

SHANER, G.; FINNEY, R. E. The effect of nitrogen fertilization on the expression of slow mildewing resistance in Knox wheat. Phytopathology, St. Paul, v. 67, p. 1051-1056, 1977.

ZEIGLER, R. S.; CUOC, L. X.; SCOTT, R. P.; BERNARDO, M. A.; CHEN, D. H.; VALENT, B.; NELSON, R. J. The relationship between lineage and virulence in Pyricularia grisea in the Philippines. Phytopathology, St. Paul, v. 85, p. 443-451, 1995. 